\title{
The Effect of Psychological Safety and Leadership Style on Risk Performance with Enterprise Risk Management as Intervening Variables
}

\author{
Aulia Himmah \\ Trisakti University \\ Yvonne Augustine \\ Trisakti University
}

\begin{abstract}
This study examines the effect of psychological safety and leadership style on risk performance with enterprise risk management as an intervening variable. The design of this study is a form of survey research, the number of samples in this study were 51 respondents intended for employees in service companies in Indonesia. The results of the study show that the direct effect given $\mathrm{X} 2$ to $\mathrm{Y}$ is 0.116 , while the indirect effect of $\mathrm{X} 2$ through $\mathrm{z}$ on $\mathrm{Y}$ is the multiplication of the value of beta $\mathrm{X} 2$ to $\mathrm{Z}$ with the beta value $\mathrm{Z}$ to $\mathrm{Y}$. Then the total effect given $\mathrm{X} 2$ to $\mathrm{Y}$ is the direct effect coupled with the indirect effect. Indirect influence $<$ direct effect, shows that indirectly X2 through $\mathrm{Z}$ does not have a significant effect on $\mathrm{Y}$.
\end{abstract}

Keywords: Psychological Safety, Leadership Style, ERM, Risk Performance

DOI: $10.7176 / \mathrm{EJBM} / 11-12-10$

Publication date: April $30^{\text {th }} 2019$

\section{Background}

At the beginning of its development, a silo (partial) based risk management perspective, also known as Traditional Risk Management (TRM). The traditional approach is still thick with sectoral ego, where each division or department does not want to share information or other things that are actually needed for mutual progress. In recent years, there has been a paradigm shift in how to view risk management, using a holistic approach. The risk management approach that makes risk management encompass all aspects and is implemented in an integrated manner, commonly called Enterprise Risk Management. ERM is the opposite of TRM. ERM is often referred to as Integrated Risk Management (IRM) and Strategic Risk Management (SRM), which offers a concept of assuming that the entire risk portfolio of the company is integrated and holistic, thus mitigating risk early and comprehensively. Furthermore risk management is part of the overall business strategy and intended to contribute to protecting and increasing shareholder value.

Risk is always present in every activity or activity carried out by the company. The bigger the company, the more risks that surround it. Therefore, companies are required to control and minimize these risks so as not to harm the stakeholders or the company itself. One way is to do risk management. Risk management as the implementation of management functions in risk management which includes activities in planning, organizing, compiling, leading / coordinating, and supervising (including evaluating) risk management programs. Risk management really needs to be done by the company to find out the possible business risks that will occur. After risk management is made, then it must be disclosed to interested parties to be taken into consideration in decision making. Especially for companies that go public, risk management disclosure is very important because the stakeholders are very numerous and diverse.

To remain viable in today's dynamic business environment, on the other hand, they are important events that are more or less unexpected. Future success is dependent on the company's ability to make appropriate responsive actions and flexibility to react timely to these changes. To follow the idea of managing a risk management system (Choi et al., 2015; Mikes and Kaplan, 2014; Power, 2009). Despite its popularity in research, the ERM field is still growing, and Mikes and Kaplan (2014, p. 3) believe that "the risk management approach is largely unproven and still developing". more research in the ERM field is a further risk management system.

The pattern of relationships that occur between superiors and subordinates can cause employees to feel happy or not happy to work in the company, for this reason in the organization planning is always done processing human resources to get the right person for the right position. One of the targets of processing human resources in the management functions of the organization is concerning leadership issues, someone who is appointed as a leader or who is recognized by members as the person who deserves to lead them, he is the one who runs the function of the organization. The manner and pattern of leader behavior is interpreted by subordinates who collaborate with him as a leadership style. According to Kartono (2005: 153) leadership is the ability to give constructive influence to others to make a cooperative effort to achieve the planned goals. Rivai (2004: 2), Leadership is a process that influences or exemplifies followers through a process of communication in an effort to achieve organizational 
goals.

A leader in the organization must be able to create harmonious integration with his subordinates, including in fostering cooperation, leading and encouraging the work of the subordinates so as to create a positive motivation that will lead to intentions and maximum performance. achieve organizational goals. Where a leader as one part of management plays an important role in influencing and giving attitudes and behavior and groups, thus forming leadership styles that leaders apply.

It can be ascertained that the behavior of a leader is an influence that will lead to an understanding that will affect the psychological condition of the subordinates, there are subordinates who see, observe and imitate the behavior of the boss that is perceived as something that the subordinates expect will have a better impact on employee performance, conversely if the leadership behavior displayed by the boss as something that is not in line with expectations, it will have an adverse effect on employee performance.

\section{Literature Review}

2.1 Psychological Safety

Influence in involving employees in a strategic action or risk reduction is very dependent on the willingness of employees to want to participate in the company and ultimately affect the perceptions of the people concerned. This construction is based on the theory developed by Liang et al. (2012) with four items in measuring psychological safety brands that all employees in the company are able to express their own opinions and feelings, all employees can freely express their thoughts and ideas, employees feel valued for expressing their opinions and employees feel that they will be blamed or given penalties for those who have errors or opinions that are different from perfection / top management.

\subsection{Leadership Style}

The assessment of top management leadership style is based on Choi (2004). This instrument focuses specifically on participatory leadership styles, leaving other aspects of (more broadly defined) leadership leadership, such as individual work effort, duration of work or the like. This instrument comes from the construction of leadership that supports Choi (2004). The size of the four items produced asks the manager to assess the level at which top management is open to middle manager ideas and is willing to let middle managers experiment with new concepts or products on a seven-point Likert scale.

\subsection{Enterprise Risk Management}

Items are developed from the management process described in the ERM framework: COSO (2004) and ISO31000 (2009). Things that explore the extent to which the company has lasted for the past three years are considered the top priority for adopting policies to deal with strategic risk, have standard procedures to identify key risks and opportunities, analyze risks and opportunities as a basis for determining how they should be managed, have standard procedures in place to launch risk reduction activities, regularly prepare risk reports for top management and have standard procedures to monitor key risk developments and risk reduction activities launched.

\subsection{Risk Performance}

Risk performance is measured by three items designed to reveal the performance of relative risk management over the past three years compared to the sector in general. The respondents were asked to rate on a seven-point Likert scale (1 significantly worse; 7) much better, how companies have performed compared to sectors in their ability to protect known risks and uncertainties, the ability to react and reduce risks and capabilities that unexpected to take advantage of new opportunities. All latent constructs are measured by several items, thus increasing construct validity. Internal consistency and reliability were assessed by Cronbach's $\alpha$, factorloading, compositereliability (CR) and average change (AVE) for all latent variables.

\section{Conceptual Framework}

The conceptual framework is a series where there is an arrangement of thoughts that can produce a hypothesis. In this study, researchers used risk performance as a dependent variable, psychology of safety and leadership style as independent variables and enterprise risk management as an intervening variable. 


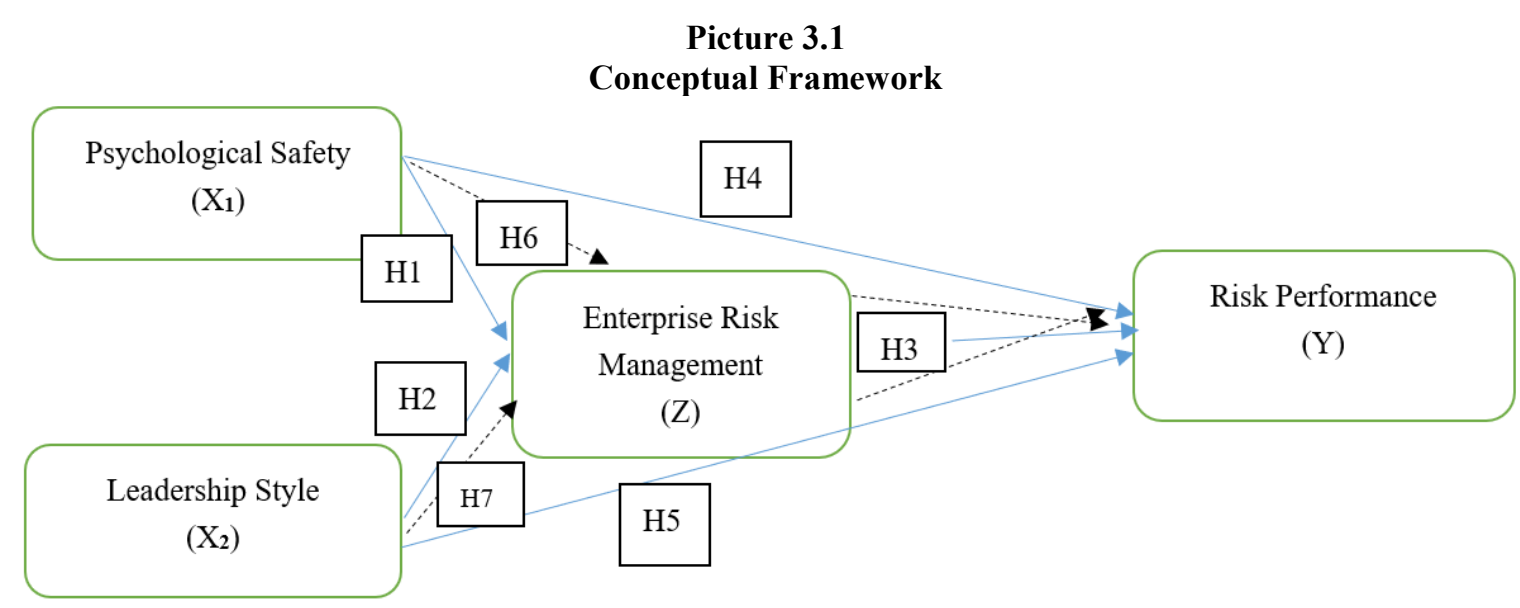

\section{Methodology of the Study \\ 4,1 Sample and Data}

The design of this study is a form of survey research. According to Handayani et al (2012), survey research is a study in which data and information are collected from respondents using a questionnaire and using a data collection and information technique that is done by compiling a list of questions aimed at the respondents in question where respondents in this study are manufacturing companies in Indonesia.

In this study, the data source used is primary data where data in the form of a questionnaire distributed and intended for employees in service companies. The number of respondents needed in this study was 51 respondents

The method of data collection used in this study is a purposive sampling technique with certain criteria that researchers have determined where these criteria are employees of manufacturing companies in Indonesia with a minimum level of manager equivalent or more. The theory in this study was obtained from literature, journals, and results of previous studies. This method is used to understand and study the literature-literature that contains a discussion that is closely related to this research. In addition, researchers used the results of questionnaires to calculate each variable using statistical tests to smooth and support this study.

\subsection{Measurement}

The hypothesis in this study was tested by using data quality test in the form of validity test and data reliability test to obtain a comprehensive picture of the influence between independent variables, namely psychological safety and leadership style with the dependent variable, risk performance and enterprise risk management as intervening variables. Before testing the data quality, descriptive statistical analysis is carried out first.

\section{Table 4.1}

Measurement

\begin{tabular}{|c|c|c|c|}
\hline No & Variable & Definition & Intrument \\
\hline 1 & $\begin{array}{l}\text { Risk } \\
\text { Performance }\end{array}$ & $\begin{array}{l}\text { A structured approach / } \\
\text { methodology for managing } \\
\text { uncertainties related to threats; a } \\
\text { series of human activities } \\
\text { including: Risk assessment, } \\
\text { development of strategies to } \\
\text { manage it and risk mitigation by } \\
\text { using empowerment / resource } \\
\text { management. }\end{array}$ & $\begin{array}{l}1 \text { The company has the ability to protect the } \\
\text { important value of the risks and uncertainties that } \\
\text { occur } \\
2 \text { Companies have the ability to react and reduce } \\
\text { unexpected risks } \\
3 \text { The company has the ability to exploit new } \\
\text { opportunities } \\
4 \text { Companies have the ability to be sensitive to } \\
\text { emerging risks that can affect company performance }\end{array}$ \\
\hline 2 & $\begin{array}{l}\text { Psychological } \\
\text { Safety }\end{array}$ & $\begin{array}{l}\text { shared belief that this team is } \\
\text { safe for interpersonal risk taking. } \\
\text { This can be defined as "being } \\
\text { able to show and employ } \\
\text { yourself without fearing the } \\
\text { negative consequences of self- } \\
\text { image, status or career" }\end{array}$ & $\begin{array}{l}\text { 1. You can freely channel your opinions and } \\
\text { feelings. } \\
2 \text { You can freely express your ideas and thoughts } \\
3 \text { If you can channel your opinions and thoughts, the } \\
\text { company will appreciate you } \\
4 \text { The company will not give a penalty to someone } \\
\text { who has a different opinion from top management }\end{array}$ \\
\hline
\end{tabular}




\begin{tabular}{|c|c|c|c|}
\hline No & Variable & Definition & Intrument \\
\hline 3 & $\begin{array}{l}\text { Leadership } \\
\text { Style }\end{array}$ & $\begin{array}{l}\text { A set of characteristics used by } \\
\text { leaders to influence subordinates } \\
\text { so that organizational goals are } \\
\text { achieved or it can also be said } \\
\text { that leadership styles are } \\
\text { behavioral patterns and } \\
\text { strategies that are liked and often } \\
\text { applied by a leader. }\end{array}$ & $\begin{array}{l}1 \text { Top Management will actively evaluate the } \\
\text { opinions and ideas of its employees } \\
2 \text { Top management will open and accept new ideas } \\
\text { and initiatives from its employees } \\
3 \text { Top management will appreciate all experiences } \\
\text { with new ideas and superior products } \\
4 \text { Top management will ensure that employee } \\
\text { interest will increase in making strategic decisions }\end{array}$ \\
\hline 4 & $\begin{array}{l}\text { Enterprise } \\
\text { Risk } \\
\text { Management }\end{array}$ & $\begin{array}{l}\text { a process that is influenced by } \\
\text { the board of directors, and other } \\
\text { personnel of an organization, } \\
\text { applied in strategy settings, and } \\
\text { covers the organization as a } \\
\text { whole, designed to identify } \\
\text { potential events that affect an } \\
\text { organization, to provide } \\
\text { reasonable guarantees regarding } \\
\text { the achievement } \\
\text { organizational goals }\end{array}$ & $\begin{array}{l}1 \text { The company has a policy to handle risks that } \\
\text { occur with the ability to achieve strategic goals } \\
2 \text { The company has standard procedures to identify } \\
\text { opportunities and risks that occur } \\
3 \text { Companies can manage well to manage } \\
\text { opportunities and risks } \\
4 \text { Companies have standard procedures to reduce } \\
\text { opportunities and risks }\end{array}$ \\
\hline
\end{tabular}

\section{Result and Discussion}

\subsection{Demographic Data}

Before discussing the results of 51 respondents to the questionnaire that the researcher spread, first the researcher will discuss the general description of the respondents themselves. The general description of the respondents shows everything that is closely related to the respondents themselves individually.

The characteristics of the research respondents were profiles of 51 respondents who participated in filling out the research questionnaire. Profile of respondents explained about gender, age, length of work, education level, and occupation.

Table 5.1

Demographic Data

\begin{tabular}{|c|c|c|}
\hline \multicolumn{3}{|c|}{ Gender } \\
\hline & Frequency & Percent \\
\hline Man & 28 & 54.9 \\
\hline Woman & 23 & 45.1 \\
\hline Total & 51 & 100 \\
\hline \multicolumn{3}{|c|}{ Education } \\
\hline & Frequency & Percent \\
\hline Senior High School & 10 & 19.6 \\
\hline Bachelor & 21 & 41.2 \\
\hline Master & 20 & 39.2 \\
\hline Total & 51 & 100 \\
\hline \multicolumn{3}{|c|}{ Length of Work } \\
\hline & Frequency & Percent \\
\hline$<1$ years & 5 & 9.8 \\
\hline $1-2$ years & 18 & 35.3 \\
\hline $3-4$ Years & 14 & 27.5 \\
\hline$>5$ Years & 14 & 27.5 \\
\hline Total & 51 & 100 \\
\hline \multicolumn{3}{|c|}{ Age } \\
\hline & Frequency & Percent \\
\hline $18-21$ & 2 & 3.9 \\
\hline $22-24$ & 11 & 21.6 \\
\hline $25-27$ & 10 & 19.6 \\
\hline $28-30$ & 13 & 25.5 \\
\hline$>30$ & 14 & 27.5 \\
\hline Total & 51 & 100 \\
\hline
\end{tabular}




\subsection{Descriptive Statistics}

The frequency distribution of the study is elaborated on the characteristics of the study such as: number of observations, minimum values, maximum values, mean values, standard deviations and modes.

Table 5.2

Descriptive Statistics

\begin{tabular}{|c|c|c|c|c|}
\hline & Psychological Safety & Leadership Style & ERM & Risk Performance \\
\hline N Valid & 51 & 51 & 51 & 51 \\
Missing & 0 & 0 & 0 & 0 \\
\hline Mean & 3.3392 & 3.6422 & 3.4657 & 3.4559 \\
\hline Median & 3.2500 & 3.7500 & 3.5000 & 3.5000 \\
\hline Mode & 3.50 & 3.75 & 3.50 & 3.50 \\
\hline Std Deviation & 0.29506 & 0.28834 & 0.22372 & 0.27252 \\
\hline Minimum & 2.50 & 3.00 & 2.75 & 2.25 \\
\hline Maximum & 4.00 & 4.25 & 4.00 & 4.00 \\
\hline
\end{tabular}

\subsection{Validity and Realibility Test}

Table 5.3

Validity and Realibility Test

\begin{tabular}{|c|c|c|}
\hline Psychological Safety & Validity $(>0.3)$ & Realibility \\
\hline $\mathrm{Q} 1$ & 0.525 & \multirow{4}{*}{0.620} \\
\hline $\mathrm{Q} 2$ & 0.455 & \\
\hline Q3 & 0.535 & \\
\hline Q4 & 0.482 & \\
\hline Leadership Style & Validity $(>0.3)$ & Realibility \\
\hline Q5 & 0.456 & \multirow{4}{*}{0.589} \\
\hline Q6 & 0.404 & \\
\hline Q7 & 0.534 & \\
\hline Q8 & 0.508 & \\
\hline ERM & Validity $(>0.3)$ & Realibility \\
\hline Q9 & 0.625 & \multirow{4}{*}{0.462} \\
\hline Q10 & 0.003 & \\
\hline Q11 & 0.332 & \\
\hline Q12 & 0.623 & \\
\hline Risk Performance & Validity $(>0.3)$ & Realibility \\
\hline Q13 & 0.576 & \multirow{4}{*}{0.574} \\
\hline Q14 & 0.467 & \\
\hline Q15 & 0.372 & \\
\hline Q16 & 0.439 & \\
\hline
\end{tabular}

\subsection{Path Analysis}

In this study the method used is Path Analysis. Path analysis is a development technique from multiple linear regression. This technique is used to test the amount of contribution (contribution) shown by the path coefficient on each path diagram of the causal relationship between variables X1 X2 and X3 to Y and its impact on Z. Path analysis using SPSS version 22 software uses 2 path analysis. The first path analysis is: 
Table 5.4

First Path Analysis

Variables Entered/Remoneda

\begin{tabular}{|l|c|c|c|}
\hline Model & $\begin{array}{c}\text { Mariables } \\
\text { Entered }\end{array}$ & $\begin{array}{c}\text { Variables } \\
\text { Femoved }\end{array}$ & Method \\
\hline 1 & LEADERSHIP & & \\
STYLE & & & Enter \\
& PSYCHOLOG & & \\
& IOALSAETY & & \\
\hline
\end{tabular}

a. Dependent Variable: ERM

b. All requested variables entered.

Coefficients $^{a}$

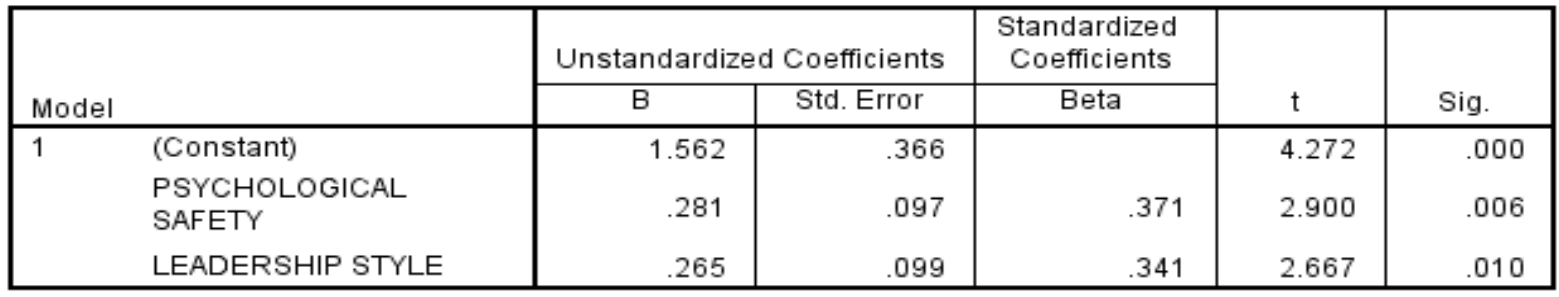

a. Dependent Variable: ERM

Model Summary

\begin{tabular}{|l|l|r|r|r|}
\hline Model & $\mathrm{R}$ & R Square & $\begin{array}{c}\text { Adjusted } \\
\text { Square }\end{array}$ & $\begin{array}{c}\text { Std. Error of } \\
\text { the Estimate }\end{array}$ \\
\hline 1 & $.604^{a}$ & .365 & .338 & .18198 \\
\hline
\end{tabular}

a. Predictors: (Constant), LEADERSHIP STYLE, PSYCHOLOGICAL SAFETY

ANOVA ${ }^{a}$

\begin{tabular}{|ll|r|r|r|c|c|}
\hline Model & & $\begin{array}{c}\text { Sum of } \\
\text { Squares }\end{array}$ & df & Mean Square & F & Sig. \\
\hline 1 & Regression & .913 & 2 & .456 & 13.782 & $.000^{\mathrm{b}}$ \\
& Residual & 1.590 & 48 & .033 & \\
& Total & 2.502 & 50 & & \\
\end{tabular}

a. Dependent Variable: ERM

b. Predictors: (Constant), LEADERSHIP STYLE, PSYCHOLOGICAL SAFETY 
Table 5.5

Second Path Analysis

Wariables Erutereahremonneda

\begin{tabular}{|c|c|c|c|}
\hline ModeI & $\begin{array}{c}\text { Wariables } \\
\text { Entered }\end{array}$ & $\begin{array}{l}\text { Mariables } \\
\text { Fermoved }\end{array}$ & M1 \\
\hline 1 & $\begin{array}{l}\text { EFF, } \\
\text { LEALEFSHIF } \\
\text { PTSLE. } \\
\text { IAL SAFETL }\end{array}$ & & Emter \\
\hline
\end{tabular}

a. Dependent variable: FISHEFFFGFRACE

b. All requested variables entered.

Coefficients $^{a}$

\begin{tabular}{|c|c|c|c|c|c|c|}
\hline \multicolumn{2}{|c|}{ Model } & \multicolumn{2}{|c|}{ Unstandardized Coefficients } & $\begin{array}{c}\begin{array}{c}\text { Standardized } \\
\text { Coefficients }\end{array} \\
\text { Beta }\end{array}$ & $\mathrm{t}$ & Sig. \\
\hline \multirow[t]{3}{*}{1} & (Constant) & 1.788 & .617 & & 2.897 & .006 \\
\hline & LEADERSHIP STYLE & .110 & .153 & .116 & .718 & .476 \\
\hline & ERM & .302 & .207 & .248 & 1.457 & .152 \\
\hline
\end{tabular}

a. Dependent Variable: RISK PERFORMANCE

Model Summary

\begin{tabular}{|l|r|r|r|r|}
\hline Model & F & F Square & $\begin{array}{c}\text { Adjusted } \\
\text { Square }\end{array}$ & $\begin{array}{c}\text { Std. Error of } \\
\text { the Estimate }\end{array}$ \\
\hline 1 & $.367 a$ & .135 & .080 & .26144 \\
\hline
\end{tabular}

a. Predictors: (Constant), ERM, LEADERSHIP STYLE, PSYCHOLOGICAL SAFETY

ANOVAa

\begin{tabular}{|ll|r|r|r|r|c|}
\hline Model & & Sum of & df & Mean Square & F & Sig. \\
\hline 1 & Regression & .501 & 3 & .167 & 2.443 & $.076^{\mathrm{b}}$ \\
& Residual & 3.212 & 47 & .068 & \\
& Total & 3.713 & 50 & & \\
\hline
\end{tabular}

a. Dependent Variable: RISK PERFORMANCE

b. Predictors: (Constant), ERM, LEADERSHIP STYLE, PSYCHOLOGICAL SAFETY

\section{Conclusion}

6.1 Summary

This study aims to examine the effect of psychological safety and leadership style on risk performance with enterprise risk management as an intervening variable. The sample in this study are employees who work in service companies. The sampling process in this study used a purposive sampling technique and used 51 respondents.

1. Analysis of the effect of X1 on Z

The sig value $\mathrm{x} 1=0.006<0.05$, so that it can be concluded that directly there is a significant effect of Psychological Safety on ERM.

2. Analysis of the effect of $\mathrm{X} 2$ on $\mathrm{Z}$

The value of sig $\mathrm{x} 2=0.010<0.05$, so that it can be concluded that directly there is a significant effect of Leadership Style on ERM.

3. Analysis of the influence of $\mathrm{Z}$ on $\mathrm{Y}$

The sig value $\mathrm{x} 1=0.152<0.05$, so that it can be concluded that directly there is no significant effect of ERM on Risk Performance.

4. Analysis of the effect of $\mathrm{X} 1$ on $\mathrm{Y}$

The sig value $\mathrm{x} 1=0.663>0.05$, so it can be concluded that there is no significant effect of Psychological

Safety on Risk Performance.

5. Analysis of the effect of $\mathrm{X} 2$ on $\mathrm{Y}$

The sig value $\mathrm{x} 1=0.476>0.05$, so it can be concluded that directly there is no significant effect of Leadership 
Style on Risk Performance.

6. Analysis of the influence of $\mathrm{X} 1$ through $\mathrm{Z}$ on $\mathrm{Y}$

The direct effect given $\mathrm{x} 1$ to $\mathrm{Y}$ is 0.072 , while the indirect effect $\mathrm{x} 1$ through $\mathrm{z}$ to $\mathrm{Y}$ is the multiplication of the value of beta $\mathrm{X} 1$ to $\mathrm{Z}$ with the beta value $\mathrm{Z}$ to $\mathrm{Y}$ which is $0.371 \times 0.248=0.092$. then the total effect given $\mathrm{x} 1$ to $\mathrm{Y}$ is the direct effect added by the indirect effect of $0.072+0.092=0.164$.

Indirect influence $>$ direct influence, shows that indirectly $\mathrm{x} 1$ through $\mathrm{Z}$ has a significant influence on $\mathrm{Y}$.

7. Analysis of the effect of $\mathrm{X} 2$ through $\mathrm{Z}$ on $\mathrm{Y}$

The direct effect given by $\mathrm{X} 2$ on $\mathrm{Y}$ is 0.116 , while the indirect effect of $\mathrm{X} 2$ through $\mathrm{z}$ on $\mathrm{Y}$ is the multiplication of the value of beta $\mathrm{X} 2$ to $\mathrm{Z}$ with the beta value $\mathrm{Z}$ to $\mathrm{Y}$ which is $0.341 \times 0.248=0.084$. then the total effect given $\mathrm{X} 2$ to $\mathrm{Y}$ is the direct effect coupled with the indirect effect of $0.116+0.084=0.2$

Indirect influence $<$ direct effect, shows that indirectly $\mathrm{X} 2$ through $\mathrm{Z}$ does not have a significant effect on $\mathrm{Y}$.

\subsection{Limitation}

This study has limited research that can be a consideration for researchers to get better results.

1. This study only uses 51 respondents, who feel that the number is still small so that they cannot provide a maximum picture.

2. The number of respondents who are not willing to fill out questionnaires with certain reasons so that it is difficult to find respondents who want to help researchers in filling out the questionnaire.

\subsection{Suggestion}

Based on the conclusions and limitations of the study, the suggestions that can be given are as follows:

1. For further research it is expected to use a wider population

2. Adding other variables such as independent variables that are thought to affect risk performance

3. Looking for a better and objective questionnaire so that it can describe the whole in determining each independent variable affects the dependent variable. 